\title{
Analisis Kualitas Website Integrated Lab Journal Menggunakan Webqual Dan Importance Performance Analysis
}

\author{
Agus Mulyanto*1 $^{1}$, Malahayati ${ }^{2}$, Annisa Khodista Syaka ${ }^{3}$, Medi Yanuarto ${ }^{4}$ \\ ${ }^{1,3}$ Program Studi Teknik Informatika, ${ }^{2}$ Program Studi Matematika, ${ }^{4}$ Program Studi Teknik \\ Industri \\ Fakultas Sains dan Teknologi Universitas Islam Negeri Sunan Kalijaga, Yogyakarta \\ e-mail: *11agus.mulyanto@uin-suka.ac.id, ${ }^{2}$ malahayati_01@yahoo.co.id, \\ syakaannisa@gmail.com, ${ }^{4}$ medi_uin@yahoo.com
}

\begin{abstract}
Abstrak
Website Integrated Lab Journal merupakan salah satu website e-journal yang diterbitkan oleh Universitas Islam Negeri Sunan Kalijaga Yogyakarta sebagai media untuk makalah ilmiah tentang pendidikan laboratorium. Instrumen penelitian ini menggunakan metode webqual yang terdiri dari 3 variabel yaitu usability (kegunaan), information quality (kualitas informasi), dan service interaction quality (kualitas interaksi layanan) dan 23 indikator. Analisis Importance Performance Analysis (IPA) dalam penelitian ini mengidentifikasi indikator-indikator yang perlu dipertahankan atau diperbaiki berdasarkan persepsi dan harapan pengguna. Pengujian webqual melibatkan 100 orang akademisi dari berbagai universitas di Indonesia. Nilai kesenjangan paling tinggi terdapat pada variabel usability (kegunaan) yaitu u5 mengenai tampilan website yang menarik dengan nilai kesenjangan -0.830. Hasil analisis IPA menunjukan indikator yang memerlukan perbaikan yaitu u3, i4, i6, dan s3. Indikator-indikator tersebut berhubungan dengan kemudahan navigasi website, informasi yang relevan dan sesuai kebutuhan pengguna, informasi yang rinci dan lengkap, dan rasa aman ketika memberikan informasi pribadi. Indikator yang dinilai baik oleh pengguna terdapat dalam kuadran I, yaitu $u 1, u 4, u 7, u 10, i 1, i 2, i 5, s 2$, dan s6. Indikator-indikator tersebut berhubungan dengan kemudahan pengoperasian, kemudahan penggunaan, pelaksaan fungsi yang baik, pencarian yang efektif, keakuratan informasi, informasi dapat dipercaya, informasi mudah dimengerti, kepercayaan publikasi, dan keyakinan proses editorial.
\end{abstract}

Kata kunci: E-journal, Integrated Lab Journal, Webqual, Importance Performance Analysis (IPA)

\begin{abstract}
The Integrated Lab Journal website is an e-journal website published by Sunan Kalijaga Yogyakarta State Islamic University as a medium for scientific papers on laboratory education. This research instrument uses the webqual method which consists of 3 variables, namely usability, information quality, and service interaction quality and 23 indicators. Importance Performance Analysis (IPA) analysis in this study identifies indicators that need to be maintained or improved based on user perceptions and expectations. Webqual Testing involved 100 academics from various universities in Indonesia. The highest gap value is found in the usability variable ( $u 5)$, which is $u 5$ regarding the appearance of an attractive website with a gap value of -0.830 . The results of the IPA analysis show indicators that need improvement, namely $u 3, i 4, i 6$, and s3. These indicators relate to the ease of navigating the website, relevant information and according to user needs, detailed and complete information, and a sense of security when providing personal information. Indicators that are rated good by
\end{abstract}


the user are in quadrant $I$, namely $u 1, u 4, u 7, u 10, i 1, i 2, i 5, s 2$, and s6. These indicators relate to ease of operation, ease of use, good functioning, effective search, accuracy of information, reliable information, easy to understand information, confidence in publication, and confidence in the editorial process.

Keywords: E-journal, Integrated Lab Journal, Webqual, Importance Performance Analysis (IPA)

\section{PENDAHULUAN}

Beriringan dengan perkembangan teknologi informasi yang terus berkembang turut memunculkan berbagai inovasi berbasis teknologi informasi salah satunya adalah jurnal dalam bentuk elektronik. Jurnal dalam bentuk elektronik (e-journal) di nilai menjadi sarana komunikasi formal yang efektif dalam menyebarkan hasil penelitian yang telah dilakukan oleh peneliti atau akademisi. Hal ini disebabkan karena e-journal diterbitkan secara berkala dan lebih cepat, dan mudah didistribusikan melalui website [1].

Keuntungan e-journal sebagai media penyebaran ilmu pengetahuan yang efektif membuat banyak organisasi atau institusi akademik mulai mengembangkan e-journal. Salah satu pengerapan e-journal di institusi akademik adalah website Integrated Lab Journal yang dapat diakses pada laman http://ejournal.uin-suka.ac.id/pusat/integratedlab/index. Website Integrated Lab Journal merupakan salah satu website e-journal yang diterbitkan oleh Universitas Islam Negeri Sunan Kalijaga Yogyakarta sebagai media untuk makalah ilmiah tentang pendidikan laboratorium. Website ini memiliki beberapa fungsi utama, diantaranya adalah menyediakan informasi mengenai jurnal yang di publikasi Integrated Lab Journal, layanan publikasi jurnal berupa pengiriman jurnal, proses editorial jurnal, dan penerbitan jurnal.

Jurnal Integrated Lab Journal memiliki tiga fokus dan ruang lingkup, yaitu alat, peralatan atau mesin pendidikan laboratorium contoh penerapannya adalah pemeliharaan dan keamanan prosedur dan instalasi rekayasa dan desain instrumentasi dan kontrol mekanisme dan konstruksi, selanjutnya materil, barang, bahan, komponen, suku cadang untuk pendidikan laboratorium contoh penerapannya adalah penyimpanan dan inventaris data dan spesifikasi pemurnian senyawa campuran, dan yang terakhir adalah metode untuk pendidikan laboratorium.

Hingga saat ini pengujian kualitas terhadap website Integrated Lab Journal belum pernah dilakukan. Oleh karena itu, diperlukan pengujian untuk mengukur kualitas website sebagai bahan pertimbangan dalam pengembangan website e-journal. Metode webqual bukan satusatunya metode pengukuran kualitas website. Metode Webqual digunakan peneliti sebagai pengukuran kualitas website menggunakan persepsi pengguna. Instrumen Webqual bertujuan menemukan persepsi pengguna terhadap website yang diakses. Analisis Importance Performance Analysis (IPA) mengidentifikasi prioritas-prioritas perbaikan website. Metode Webqual dan IPA diharapkan dapat menunjukan indikator yang harus diperbaiki oleh pengembang website dan indikator yang telah memenuhi harapan pengguna.

Pertanyaan penelitian dalam paper ini adalah: (1) Indikator apakah yang memiliki nilai kesenjangan terbesar dan terkecil berdasarkan persepsi dan harapan pengguna terhadap kualitas website Integrated Lab Journal? (2) Perbaikan apa yang sebaiknya dilakukan pada pengembangan website sehingga sesuai dengan harapan pengguna dan apa yang sebaiknya dilakukan untuk mempertahankan kualitas website yang telah memebuhi harapan pengguna.

Penerapan Webqual dan IPA dalam pengujian kualitas website telah banyak dilakukan, salah satunya penelitian yang dilakukan oleh Rahmaini. Penelitian tersebut bertujuan untuk mengetahui kualitas website akademik yang dimiliki oleh lima perguruan tinggi yaitu 
Universitas Nasional, Universitas Gunadarma, UIN Syarif Hidayatullah Jakarta, STP SAHID, dan STTI I-Tech. Instrumen pada penelitian ini menggunakan metode Webqual 4.0 dengan 3 variabel yang terdiri dari 22 indikator. Teknik analisis menggunakan IPA untuk menentukan indikator-indikator yang membutuhkan perbaikan atau dipertahankan. Simpulan yang diperoleh dari nilai kesenjangan yang menunjukan nilai negatif pada setiap indikator, hal ini menunjukan bahwa kualitas website belum memenuhi harapan pengguna. Nilai kesenjangan tertinggi terdapat pada STTI I-Tech dan nilai kesenjangan terkecil dimiliki oleh Universitas Gunadarma. Hasil analisis IPA pada penelitian ini menunjukan indikator yang membutuhkan perbaikan adalah nomor 11,14, dan 21 yang berhubungan dengan keakuratan dan keterbarukan suatu informasi, detail pada informasi, dan kemudahan komunikasi pada pihak perguruan tinggi [2].

Penelitian lainnya dilakukan oleh Gustina. Penelitian ini melakukan analisis kualitas website STIA Satya Negara Palembang dengan metode Webqual 4.0 dengan 3 variabel dan pendekatan metode penelitian deskriptif kuantitatif menggunakan metode IPA. Hasil penelitian ini menunjukan bahwa terdapat kesenjangan (gap) antara tingkat kinerja (performance) dan harapan (importance). Nilai selisih dari kedua perspektif tersebut bernilai -(1.00). Berdasarkan hasil penilaian ketiga dimensi webqual 4.0, dimensi usability memiliki nilai gap sebesar -(1.13), nilai gap dimensi information quality sebesar -(0.80), dan terakhir dimensi service interaction quality memiliki selisih paling besar dengan nilai -(1.80). Simpulan dari penelitian ini adalah kualitas aktual masih belum memenuhi kualitas ideal yang diinginkan pengguna website STIA Satya Negara Palembang [3].

Penelitian selanjutnya dilakukan oleh Wibowo dkk. Penelitian ini melakukan uji usabilitas menggunakan metode webqual dan IPA pada prototipe portal Duta Tani menurut persepsi pengguna. Tujuan dari penelitian ini adalah mengetahui kualitas prototipe portal Duta Tani menurut persepsi penggunanya. Uji usabilitas pada penelitian ini melibatkan 48 responden petani dan 3 responden admin sistem. Berdasarkan hasil uji usabilitas dapat diketahui bahwa nilai kesenjangan rata-rata berada dalam kuadaran III grafik IPA dengan $-0.41 \%$. Nilai persentasi dalam pengujian waktu kegagalan mencapai 69.88\%. Hasil usabilitas dalam penelitian digunakan untuk perbaikan halaman "Forum Diskusi", dan "Tentang Kami". Perbaikan lainnya pada bagian tombol-tombol penting adalah memberikan icon yang sesuai fungsinya sehingga pengguna lebih mudah dalam berinteraksi dengan portal DutaTani [4].

\section{METODE PENELITIAN}

\subsection{Tahapan Penelitian}

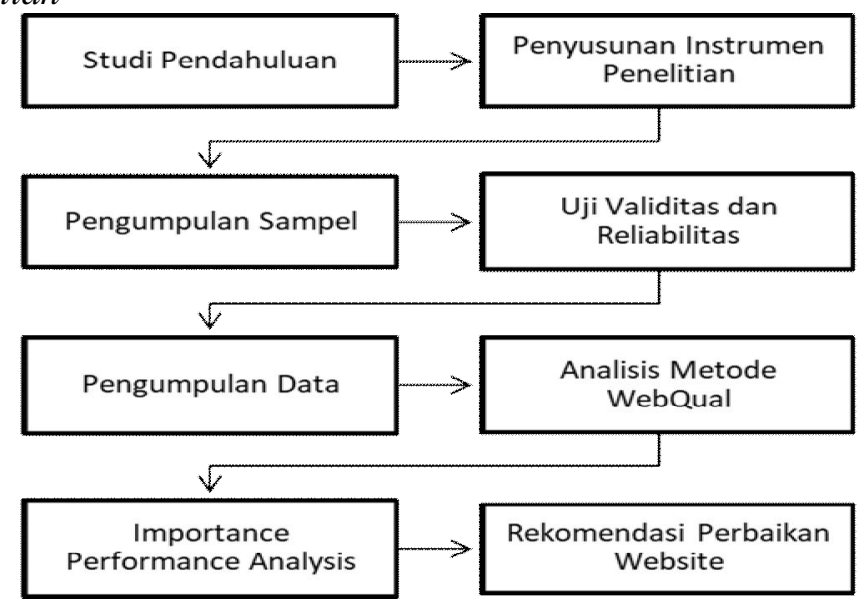

Gambar 1. Metode Penelitian 
Metode penelitian yang ditujukan pada Gambar 2 memiliki tahapan yang pertama dilakukan oleh peneliti yaitu tahap studi pendahuluan. Studi pendahuluan dilakukan dengan mempelajari dan memahami tahapan pengujian metode Webqual dan IPA. Peneliti menggunakan beragam refrensi dalam studi pendahuluan yaitu buku, jurnal ilmiah, dan penelitian terdahulu yang berkaitan dengan obyek penelitian. Tahapan penyusunan instrumen dilakukan dengan merancang kuisioner berdasarkan instrumen dalam metode Webqual 4.0. Instrumen penelitian ini terdiri dari tiga variabel yaitu usability (kegunaan), information quality (kualitas informasi), service interaction quality (kualitas intarksi layanan) dalam 23 indikator pertanyaan

Tahapan selanjutnya, peneliti melakukan pengumpulan sampel. Tujuan pengumpulan sampel adalah menemukan sampel responden yang akan menguji kuisioner pada tahapan penelitian selanjutnya. Pengumpulan sampel pada penelitian ini menggunakan media internet dalam menyebarkan kuisioner dan berhasil mengumpulkan 40 responden. Tabel 1 menunjukan indikator yang digunakan dalam kuisioner penelitian.

Tabel 1. Indikator Dalam Kuisioner

\begin{tabular}{|c|c|c|}
\hline Dimensi & Kode & Indikator \\
\hline \multirow{10}{*}{$\begin{array}{c}\text { Kegunaan } \\
\text { (Usability) } \\
\text { Kualitas } \\
\text { Informasi } \\
\text { (Information } \\
\text { quality) }\end{array}$} & $\mathrm{u} 1$ & Website mudah dipelajari cara mengoperasikannya \\
\hline & $\mathrm{u} 2$ & Interaksi dalam Website mudah dimengerti \\
\hline & u3 & Website dapat dijelajahi (dinavigasi) dengan mudah \\
\hline & $\mathrm{u} 4$ & Website mudah digunakan \\
\hline & u5 & Website memiliki tampilan yang menarik \\
\hline & u6 & $\begin{array}{l}\text { Desain Website cocok digunakan dalam jenis situs } \\
\text { e-journal }\end{array}$ \\
\hline & u7 & $\begin{array}{l}\text { Website mampu menjalankan fungsi yang baik sebagai } \\
\text { e-journal }\end{array}$ \\
\hline & u8 & $\begin{array}{l}\text { Website mampu menciptakan pengalaman positif pada } \\
\text { Anda }\end{array}$ \\
\hline & u9 & $\begin{array}{l}\text { Website memiliki tautan (hyperlinks) yang valid dan } \\
\text { mudah dimengerti }\end{array}$ \\
\hline & $\mathrm{u} 10$ & Website memiliki fitur pencarian yang efektif \\
\hline \multirow{10}{*}{$\begin{array}{l}\text { Kualitas } \\
\text { Interaksi } \\
\text { Layanan } \\
\text { (Interaction } \\
\text { service } \\
\text { quality) }\end{array}$} & i1 & Website menyediakan informasi yang akurat \\
\hline & $\mathrm{i} 2$ & Website menyediakan informasi yang terpercaya \\
\hline & i3 & $\begin{array}{l}\text { Website menyediakan informasi secara berkala (up to } \\
\text { date) }\end{array}$ \\
\hline & i4 & $\begin{array}{l}\text { Website menyediakan informasi yang relevan sesuai } \\
\text { dengan kebutuhan pengguna }\end{array}$ \\
\hline & i5 & Website menyediakan informasi yang mudah dimengerti \\
\hline & i6 & $\begin{array}{l}\text { Website menyediakan informasi dengan rincian yang } \\
\text { lengkap }\end{array}$ \\
\hline & i7 & $\begin{array}{l}\text { Website menyajikan informasi dalam format penulisan } \\
\text { yang baik }\end{array}$ \\
\hline & s1 & Website memiliki reputasi yang baik di mata penggunanya \\
\hline & s2 & $\begin{array}{l}\text { Website memberikan rasa percaya dalam melakukan } \\
\text { publikasi hasil penelitian }\end{array}$ \\
\hline & s3 & $\begin{array}{l}\text { Website memberikan rasa aman pada infromasi pribadi } \\
\text { yang diberikan }\end{array}$ \\
\hline
\end{tabular}

Mulyanto, et., al [Analisis Kualitas Website Integrated Lab Journal Menggunakan Webqual dan Importance Performance Analysis] 


\begin{tabular}{|c|c|l|}
\hline & s4 & $\begin{array}{l}\text { Website membuat saya menjadi bagian dari suatu } \\
\text { komunitas yang berperan dalam } \text {-journal Integrated Lab } \\
\text { Journal }\end{array}$ \\
\cline { 2 - 3 } & s5 & $\begin{array}{l}\text { Website memberikan kemudahan dalam berkomunikasi } \\
\text { dengan admin web e-journal Integrated Lab Journal }\end{array}$ \\
\cline { 2 - 3 } & s6 & $\begin{array}{l}\text { Website memberikan keyakinan bahwa paper yang } \\
\text { disubmit akan melalui proses editor sebelum dipublikasi }\end{array}$ \\
\hline
\end{tabular}

Tahapan pengujian sampel dilakukan dengan uji validitas dan reliabilitas. Pengujian validitas mengukur kelayakan instrumen-instrumen dalam kuisioner penelitian dan pengujian reliabilitas mengukur kehandalan instrumen-instrumen dalam kuisioner penelitian.

Tahap penelitian berikutnya adalah pengumpulan data. Peneliti menentukan responden dalam tahapan penelitian ini dengan mengunjungi beberapa universitas dan mengambil sampel secara acak. Responden yang bergabung dalam penelitian, yaitu mahasiswa yang sedang S1, mahasiswa telah menempuh pendidikan S1, dan S2. Kuisioner yang akan digunakan dalam pengumpulan data terdiri dari beberapa bagian, yaitu informasi yang menyajikan tujuan utama pengumpulan data dalam penelitian, responden diminta untuk mengisi data diri yang selanjutnya disediakan informasi panduan pengisian kuisioner, responden diminta menjawab pertanyaan yang diajukan oleh peneliti, dan terakhir adalah ucapan terima kasih. Pengisian kuisioner dilakukan oleh responden dengan memberikan jawaban menggunakan skala linkert 1-5 dengan aturan nilai yaitu, 1 bernilai sangat tidak setuju, 2 bernilai tidak setuju, 3 bernilai biasa saja, 4 bernilai setuju, dan 5 bernilai sangat setuju.

Data yang telah diperoleh dari tahapan sebelumnya akan digunakan pada tahap analisis Webqual dan importance performance analysis. Hasil analisis digunakan oleh peneliti untuk menentukan perbaikan yang akan dilakukan pada sistem lama. Perbaikan yang dilakukan atas rekomendasi hasil analisis diharapkan dapat memperbaiki nilai kesenjangan antara harapan dan kinerja dari sistem e-journal Integrated Lab Journal yang sebelumnya.

\section{2 Studi Pustaka}

\section{2.1 Uji Validitas}

Menurut Nisfiannoor penggunaan angket sebagai alat pengambilan data penelitian perlu memenuhi kriteria tertentu sehingga memberikan informasi yang terpercaya. Kriteria yang dimaksud adalah validitas dan reliabilitas yang baik. Kriteria tersebut dapat terpenuhi apabila hasil pengukuran validitas dan reliabilitas memiliki tingkat yang tinggi. Instrumen ukur yang tidak valid dan tidak reliabel akan memberikan informasi yang tidak akurat pada keadaan responden. Sehingga uji validitas digunakan untuk mengetahui tingkat validitas dari instrumen ukur penelitian ini [5].

Uji validitas dapat digunakan untuk mengetahui apakah kuisioner tersebut sah atau valid. Kusioner yang dikatakan valid memiliki pertanyaan kuisioner yang menggambarkan sesuatu yang akan diukur dalam kuisioner. Mengukur tingkat validitas dapat dilakukan dengan menghitung korelasi antara skor setiap pertanyaan dengan total skor. Melakukan uji validitas dengan SPSS [6].

1. Buka file Input SPSS yang telah diisi oleh hasil kuisioner.

2. Memilih menu statistic/ analyze, setelah itu pilih submenu correlate, dan terakhir pilih bivariate.

3. Box variable akan muncul, masukan setiap pertanyaan dalam satu konteks dan satu jumlah setiap konteks.

4. Memilih coeficient correlation pearson.

5. Terakhir pilih OK untuk melihat hasil uji validitas dalam lembar kerja output dalam SPSS. 
Hasil uji validitas dapat ditentukan dengan memperhatikan hasil output SPSS. Membandingkan nilai corrected item-total correlation dengan nilai $r$ tabel pada level signifikan 0.05. Nilai corrected item-total correlation lebih besar dari nilai $\mathrm{r}$ tabel maka dikatakan valid jika lebih kecil dikatakan tidak valid dan harus dihilangkan dari pengolahan data [7].

\section{2.2 Uji Reliabilitas}

Relibilitas memiliki pengertian sebagai alat ukur suatu kuisioner yaitu indikator dari variabel atau kelompok. Pertanyaan dalam kuisioner dinyatakan relibilitas jika jawaban seseorang terhadap pertanyaan konsisten. Pengkuran rebilitas dapat dilakukan dengan dua cara [8].

\section{Repeated measure (pengukuran ulang)}

Seorang responden diberi pertanyaan dan alternatif jawaban yang sama dalam waktu yang berbeda. Pertanyaan dikatakan handal jika jawaban yang diberikan masih sama.

2. One shot (pengukuran sekali saja)

Kuisioner disebarkan kepada responden, kemudian pengukuran kehandalan pertanyaan dengan hasil skor jawaban responden. Hasil skor tersebut diukur korelasinya dengan skor jawaban pada butir pertanyaan dengan bantuan SPSS. Pada program SPSS akan menggunakan fasilitas cronbach Alpha. Konstruk atau variabel yang relibilitas jika nilai cronbach alpha melebihi 0.06 .

Relibilitas dilakukan untuk mengetahui apakah hasil pengukuran yang dilakukan tetap konsisten meskipun dilakukan pengukuran kembali oleh orang yang sama pada waktu yang berbeda atau orang yang berbeda pada waktu yang sama. Uji relibilitas untuk mengukur tinggi atau rendahnya relibilitas tidak dapat ditentukan dengan pasti. Solusi lain yaitu uji reablitas digunakan untuk melakukan estimasi terhadap relibilitas suatu alat ukur. Pendekatan yang dilakukan untuk menentukan koefisien relibilitas pada suatu alat ukur dibagi mejadi tiga cara [5].

1. Ukur Ulang (Test Retest)

2. Ukur Setara (Parallel Form/Equivalent Form/Alternative Form)

3. Sekali Ukur (One Shot)

Uji relibilitas digunakan untuk mengetahui konsistensi hasil pengukuran satu instrumen jika instrumen tersebut digunakan kembali sebagai alat ukur responden. Hasil uji reabilitas menentukan apakah instrumen penelitian dapat dipercaya atau tidak berdasarkan tingkat pemantapan dan ketepatan alat ukur, atau dengan kata lain hasil pengukuran yang didapatkan merupakan ukuran yang benar dari suatu yang diukur [7].

Melakukan uji reabilitas dengan SPSS [6].

1. Buka file Input SPSS yang telah diisi oleh hasil kuisioner.

2. Memilih menu statistic/analyze, selanjutnya pilih menu scale lalu pilih reability analysis.

3. Box reability analysis akan muncul, masukan setiap pertanyaan dalam satu konteks dan satu jumlahnya.

4. Memilih Model Alpha dalam kotak reability analysis

5. Terakhir pilih OK untuk melihat hasil uji validitas dalam lembar kerja output dalam SPSS.

Hasil uji relibilitas dapat ditentukan dengan memperhatikan hasil output relibilitas SPSS.

Membandingkan nilai cronbach alpha dalam reliability statistic. Jika nilai cronbach alpha lebih besar dari minimal nilai cronbach alpha (0.6) maka instrumen penelitian yang digunakan dapat dikatakan realibel atau handal namun jika sebaliknya nilai cronbach alpha lebih kecil maka dapat dikatakan tidak realibel. 


\section{2.3 Webqual 4.0}

Penelitian terdahulu tentang Webqual dan NetQual (Penilaian kinerja website). Webqual 4.0 digunakan sebagai instrumen dalam pengukuran kualitas situs web.Instrumen Webqual telah melalui proses penelitian berulang-ulang sejak tahun 1998 sehingga mencapai versi terbaru yaitu Webqual 4.0. Webqual 4.0 memiliki tiga dimensi dalam penilaian kualitas web yaitu kegunaan (usability), kualitas informasi (information quality), dan kualitas insteraksi layanan (service interaction quality). Dimensi yang pertama, kegunaan menurut Barnes dan Vidgen, merupakan persepsi pengguna yang memiliki keterkaitan terhadap suatu website ketika melakukan interaksi terhadap website tersebut. Kualitas kegunaan website berhubungan dengan kemudahan dalam menggunakan situs website [9]. Selanjutnya merupakan dimensi kualitas informasi (information quality) yang dapat ditentukan dengan kesesuaian informasi dari situs web menurut pengguna. Kualitas interaksi layanan merupakan dimensi terakhir dalam Webqual 4.0. Kualitas interaksi layanan berupa kepercayaan pengguna terhadap website ketika menyimpan data maupun melakukan interaksi dalam website secara personal.

Metode Webqual 4.0 menggunakan 22 item indikator penilaian kualitas yang dikelompokan dalam tiga dimensi Webqual 4.0, Indikator webqual ditunjukan pada Tabel 1 [10].

Tabel 2. Indikator Dalam Webqual 4.0

\begin{tabular}{|c|c|}
\hline Dimensi & Indikator \\
\hline \multirow{8}{*}{$\begin{array}{l}\text { Kegunaan } \\
\text { (Usability) }\end{array}$} & $\begin{array}{lllll}\text { 1. Saya merasa mudah untuk mempelajari dan } \\
\text { mengoperasikan situs }\end{array}$ \\
\hline & 2. Interaksi saya pada situs jelas dan mudah dimengerti \\
\hline & 3. Saya merasa situs mudah dinavigasi \\
\hline & 4. Situs mudah digunakan \\
\hline & 5. Situs memiliki tampilan yang menarik \\
\hline & 6. Situs memiliki desain yang cocok dengan jenisnya \\
\hline & 7. Situs menyampaikan rasa kompetensi \\
\hline & 8. Situs menciptakan pengalaman yang po \\
\hline \multirow{7}{*}{$\begin{array}{l}\text { Kualitas } \\
\text { Informasi } \\
\text { (Information } \\
\text { quality) }\end{array}$} & 9. Memberikan informasi yang akurat \\
\hline & 10. Memberikan informasi yang terpercaya \\
\hline & 11. Memberikan informasi terbaru \\
\hline & 12. Memberikan informasi yang relefan \\
\hline & 13. Memberikan Informasi yang mudah dimengerti \\
\hline & 14. Memberikan informasi pada tingkat detail yang tepat \\
\hline & 15. Menampilkan infromasi yang sesuai \\
\hline \multirow{7}{*}{$\begin{array}{c}\text { Kualitas } \\
\text { Interaksi } \\
\text { Layanan } \\
\text { (Interaction } \\
\text { service quality) }\end{array}$} & 16. Mempunyai reputasi yang baik \\
\hline & 17. Menimbulkan rasa aman dalam melakukan transaksi \\
\hline & 18. Penggunaan Informasi pribadi terasa aman \\
\hline & 19. Menciptakan rasa personalisasi \\
\hline & 20. Menyampaikan rasa kebersamaan \\
\hline & 21. Memudahkan komunikasi dengan organisasi \\
\hline & $\begin{array}{l}\text { 22. Saya merasa percaya diri bahwa pelayanan yar } \\
\text { diberikan akan sesuai dengan perjanjian }\end{array}$ \\
\hline
\end{tabular}

\section{2.4 Importance Performance Analysis (IPA)}

Importance Performance Analysis (IPA) diperkenalkan pertama kali pada tahun 1977 oleh Martilla dan James. Tujuan matriks IPA adalah mengukur hubungan antara persepsi konsumen dan prioritas peningkatan kualitas website yang dikenal sebagai quadrant analysis 
[11]. Berdasarkan hal tersebut dapat diketahui bahwa IPA merupakan matriks untuk mengukur tingkat kualitas website dan kepentingan indikator-indikatornya untuk mencapai pengembangan website yang efektif.

IPA mengidentifikasi dan memberi rating pada indikator berdasarkan tingkat kepentingan dan akibatnya pada kinerja organiasasi. Pihak pengembang website dapat menggunakan matriks IPA sebagai indikator yang efektif untuk ditingkatkan dalam website [12]. Analisis IPA dapat lebih memahami persepsi pengguna terhadap kualitas yang diberikan dan matriks IPA dapat menunjukan tingkat kepentingan setiap indikator menurut pengguna [2].

Menurut Martilla dan James dalam Rahmaini grafik IPA dibagi menjadi empat kuadran dengan sumbu X menggmbarkan atribut performance (kualitas) dan sumbu Y menggambarkan importance (harapan). Grafik IPA ditunjukan pada Gambar 1 [2].

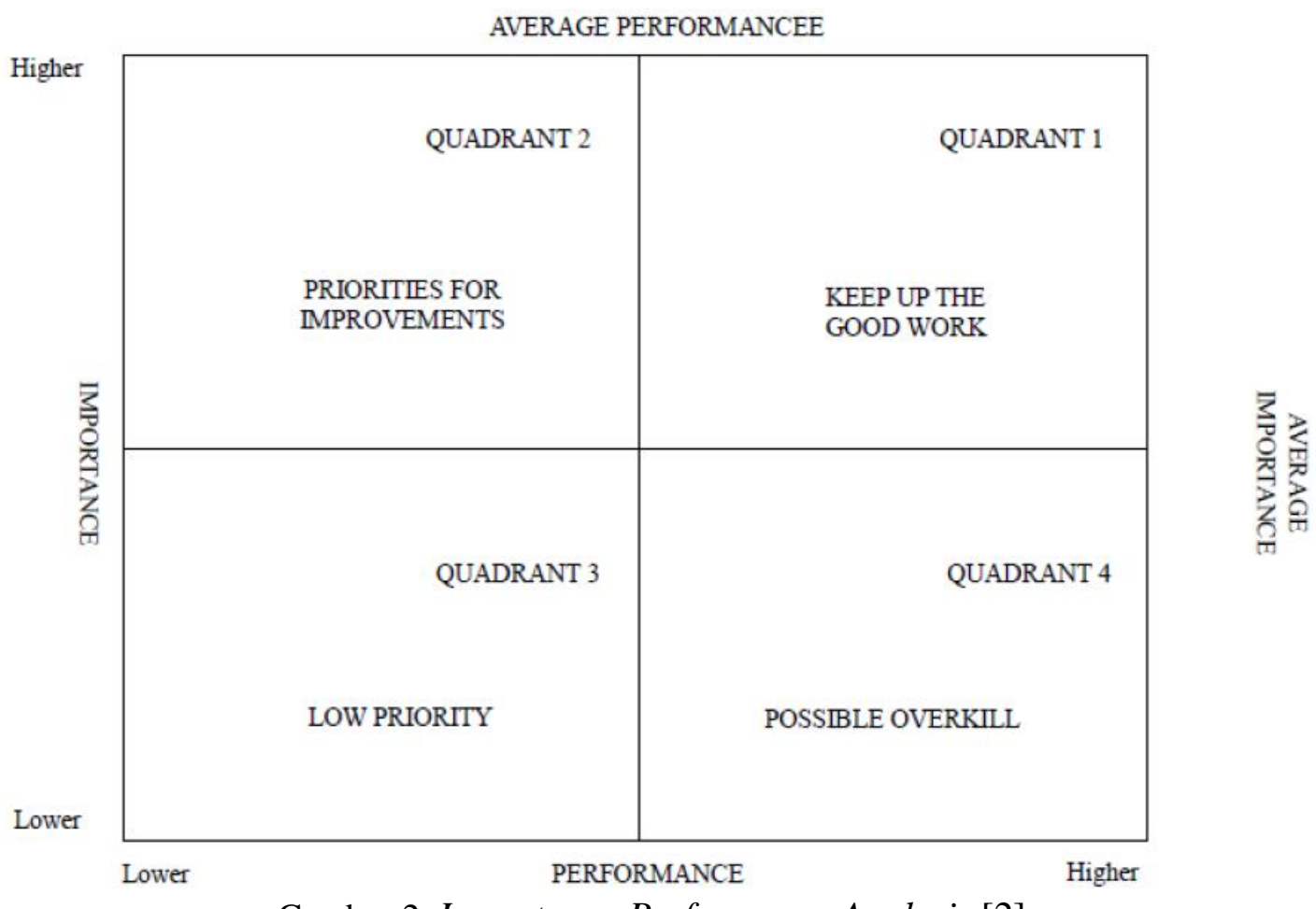

Gambar 2. Importance Performance Analysis [2].

Penjelasan masing-masing kuadran IPA pada Gambar 2 yaitu Kuadran I kondisi yang disebut Keep Up The Goodwork. (high importance and high performance). Kuadran pertama ini menggambarkan atribut-atribut yang sudah sesuai dengan yang diinginkan oleh pengguna. Hal ini dikarenakan pelayanan yang diberikan telah sesuai dengan harapan. Maka atribut-atribut yang ada pada kuadran ini harus dipertahankan. Selanjutnya kuadran II yaitu kondisi yang disebut Priorities for Improvements (high importance low performance). Kuadran kedua ini menggambarkan atribut-atribut yang masih memerlukan perbaikan dan perhatian yang lebih dari pengembang website karena pelayanan yang diberikan belum sesuai dengan yang diharapkan oleh pengguna. Kuadran III disebut kondisi Low Priority (low importance and low performance). kuadran ketiga ini menggambarkan atribut-atribut yang masuk dalam kategori low priority, yang berarti atribut-atribut tersebut atau tidak terlalu membutuhkan perhatian. Kuadran terakhir adalah kuadran IV Possibly Overkill (low importance and high performance) Kuadran keempat menggambarkan atribut yang tidak terlalu penting namun memiliki 
performance yang baik. Sehingga pengembang website dapat mengalokasikan sumber daya yang terkait dengan atribut-atribut tersebut ke tempat yang lebih membutuhkan prioritas.

Menurut Anggraini, L. D., Deoranto, P., dan Ikasari, D. M, IPA memiliki kelebihan dibanding metode lainnya yaitu dapat menunjukan indikator-indikator yang perlu ditingkatkan ataupun bahkan dikurangi. Matriks IPA dalam penelitian ini dapat memberikan gambaran kepada pengelola jurnal terhadap kualitas website Integrated Lab Journal berdasarkan hasil analisis IPA dengan indikator-indikator yang ada pada Webqual 4.0 [13].

\section{HASIL DAN PEMBAHASAN}

\section{1 Hasil Uji Validitas}

Uji validitas dalam penelitian ini berdasarkan hasil dari kuisioner yang telah disebarkan kepada 40 responden. Uji validitas melihat apakah instrumen yang digunakan dalam kuisioner dapat mengukur apa yang diinginkan. Pengujian ini membandingkan nilai corrected item-total correlation dengan nilai $r$ tabel pada level signifikan 0.05 [7]. Hasil uji validitas ditunjukan pada Tabel 3.

Tabel 3. Hasil Uji Validitas

\begin{tabular}{|c|c|c|c|c|}
\hline No & Variable & Kode & Corrected Item-Total Correlation & Keterangan \\
\hline \multirow{10}{*}{1} & \multirow{10}{*}{$\begin{array}{c}\text { Kegunaan } \\
\text { (Usability) }\end{array}$} & $\mathrm{u} 1$ & 0.522 & VALID \\
\hline & & u2 & 0.671 & VALID \\
\hline & & u3 & 0.630 & VALID \\
\hline & & $\mathrm{u} 4$ & 0.657 & VALID \\
\hline & & u5 & 0.746 & VALID \\
\hline & & u6 & 0.771 & VALID \\
\hline & & $\mathrm{u} 7$ & 0.541 & VALID \\
\hline & & u8 & 0.785 & VALID \\
\hline & & u9 & 0.605 & VALID \\
\hline & & $\mathrm{u} 10$ & 0.624 & VALID \\
\hline \multirow{7}{*}{2} & \multirow{7}{*}{$\begin{array}{l}\text { Kualitas } \\
\text { Informasi } \\
\text { (Information } \\
\text { quality) }\end{array}$} & i1 & 0.613 & VALID \\
\hline & & $\mathrm{i} 2$ & 0.718 & VALID \\
\hline & & $\mathrm{i} 3$ & 0.686 & VALID \\
\hline & & i4 & 0.728 & VALID \\
\hline & & i5 & 0.664 & VALID \\
\hline & & i6 & 0.788 & VALID \\
\hline & & i7 & 0.710 & VALID \\
\hline \multirow{6}{*}{3} & \multirow{6}{*}{$\begin{array}{c}\text { Kualitas } \\
\text { Interaksi } \\
\text { Layanan } \\
\text { (Interaction } \\
\text { service quality) }\end{array}$} & s1 & 0.625 & VALID \\
\hline & & s2 & 0.698 & VALID \\
\hline & & s3 & 0.831 & VALID \\
\hline & & s4 & 0.764 & VALID \\
\hline & & s5 & 0.702 & VALID \\
\hline & & s6 & 0.645 & VALID \\
\hline
\end{tabular}

Tabel 3 menunjukan bahwa setiap indikator Webqual pada penelitian ini mempunyai nilai corrected item-total correlation lebih besar dari 0.05. Berdasarkan hal tersebut maka seluruh instrumen penelitian ini dapat dikatakan valid. 


\section{2 Hasil Uji Reliabilitas}

Uji reliabilitas dalam penelitian ini berdasarkan hasil dari kuisioner yang telah disebarkan kepada 40 responden. Uji reliabilitas menggambarkan kehandalan setiap instrumeninstrumen yang digunakan dalam kuisioner penelitian. Pengujian ini dilakukan dengan melihat nilai cronbach's alpha. Apabila nilai cronbach's alpha melebihi nilai 0.06 maka instrumen tersebut realibel atau handal [6]. Hasil uji reliabilitas ditunjukan pada Tabel 4.

Tabel 4. Hasil Uji Reliablitas

\begin{tabular}{|c|l|c|}
\hline No & Variabel & Cronbach Alpha \\
\hline 1 & Kegunaan (Usability) & 0.852 \\
\hline 2 & Kualitas Informasi (Information quality) & 0.827 \\
\hline 3 & Kualitas Interaksi Layanan (Interaction service quality) & 0.807 \\
\hline
\end{tabular}

Hasil uji reliabilitas pada Tabel 4 menunjukan bahwa setiap variabel Webqual 4.0 memiliki nilai cronbach alpha melebihi nilai 0.06. Berdasarkan hal tersebut, dapat dikatakan bahwa instrumen penelitian ini reliabel atau handal.

\section{3 Pengujian Webqual 4.0}

Pengujian Webqual melibatkan 100 orang dengan rincian informasi demografis yang meliputi jenis kelamin, umur, dan pendidikan terakhir. Informasi demografis jenis kelamin menunjukan bahwa responden perempuan berjumlah 53 orang dan responden laki-laki berjumlah 47 orang.

Informasi demografis umur responden menunjukan bahwa responden berumur kurang dari 20 tahun berjumlah 21 orang, berumur 21 tahun sampai 25 tahun berjumlah 75 orang, berumur 26 tahun sampai 30 tahun berjumlah 2 orang, berumur 36 tahun sampai 40 tahun berjumlah 1 orang, dan berumur lebih dari 40 tahun berjumlah 1 orang. Informasi demografis pendidikan terakhir responden menunjukan bahwa responden yang masih menempuh pendidikan S1 berjumlah 81 orang, responden dengan pendidikan terakhir S1 berjumlah 7 orang, dan responden dengan pendidikan terakhir S2 berjumlah 12 orang.

Nilai rata-rata harapan dan kinerja dalam penelitian ini digunakan sebagai analisis kesenjangan (gap). Nilai kesenjangan (gap) ditentukan dengan mengurangi nilai rata-rata kinerja dengan harapan. Jika nilai nilai rata-rata kinerja dengan harapan memiliki nilai yang sama maka kualitas sudah sesuai dengan harapan pengguna. Jika ditemukan bahwa nilai kesenjangan menunjukan nilai positif maka kualitas yang ada sudah sangat sesuai dan melebihi harapan, sebaliknya jika menunjukan nilai negaif menunjukan bahwa kualitas masih belum sesuai dengan harapan pengguna. Nilai kesenjangan terdapat dalam Tabel 5.

Tabel 5. Nilai Kesenjangan Indikator Webqual 4.0

\begin{tabular}{|c|l|c|c|c|}
\hline \multirow{2}{*}{ Kode } & \multicolumn{1}{|c|}{ Indikator } & \multicolumn{2}{c|}{ Nilai Rata-rata } & \multirow{2}{*}{ Gap } \\
\cline { 3 - 4 } & & Kinerja & Harapan & \\
\hline u1 & Website mudah dipelajari cara mengoperasikannya & 3.820 & 4.380 & -0.560 \\
\hline u2 & Interaksi dalam Website mudah dimengerti & 3.670 & 4.280 & -0.610 \\
\hline u3 & Website dapat dijelajahi (dinavigasi) dengan mudah & 3.670 & 4.310 & -0.640 \\
\hline u4 & Website mudah digunakan & 3.740 & 4.340 & -0.600 \\
\hline u5 & Website memiliki tampilan yang menarik & 3.280 & 4.110 & -0.830 \\
\hline u6 & $\begin{array}{l}\text { Desain Website cocok digunakan dalam jenis situs e- } \\
\text { journal }\end{array}$ & 3.530 & 4.170 & -0.640 \\
\hline u7 & Website mampu menjalankan fungsi yang baik sebagai & 3.780 & 4.320 & -0.540 \\
\hline
\end{tabular}




\begin{tabular}{|c|c|c|c|c|}
\hline & e-journal & & & \\
\hline u8 & $\begin{array}{l}\text { Website mampu menciptakan pengalaman positif pada } \\
\text { Anda }\end{array}$ & 3.870 & 4.190 & -0.320 \\
\hline u9 & $\begin{array}{l}\text { Website memiliki tautan (hyperlinks) yang valid dan } \\
\text { mudah dimengerti }\end{array}$ & 3.670 & 4.260 & -0.590 \\
\hline $\mathrm{u} 10$ & Website memiliki fitur pencarian yang efektif & 3.730 & 4.310 & -0.580 \\
\hline i1 & Website menyediakan informasi yang akurat & 3.760 & 4.450 & -0.690 \\
\hline i2 & Website menyediakan informasi yang terpercaya & 3.990 & 4.470 & -0.480 \\
\hline i3 & $\begin{array}{l}\text { Website menyediakan informasi secara berkala (up to } \\
\text { date) }\end{array}$ & 3.710 & 4.280 & -0.570 \\
\hline i4 & $\begin{array}{l}\text { Website menyediakan informasi yang relevan sesuai } \\
\text { dengan kebutuhan pengguna }\end{array}$ & 3.700 & 4.320 & -0.620 \\
\hline i5 & $\begin{array}{l}\text { Website menyediakan informasi yang mudah } \\
\text { dimengerti }\end{array}$ & 3.790 & 4.310 & -0.520 \\
\hline i6 & $\begin{array}{l}\text { Website menyediakan informasi dengan rincian yang } \\
\text { lengkap }\end{array}$ & 3.670 & 4.330 & -0.660 \\
\hline i7 & $\begin{array}{l}\text { Website menyajikan informasi dalam format penulisan } \\
\text { yang baik }\end{array}$ & 3.790 & 4.280 & -0.490 \\
\hline s1 & $\begin{array}{l}\text { Website memiliki reputasi yang baik di mata } \\
\text { penggunanya }\end{array}$ & 3.580 & 4.270 & -0.690 \\
\hline s2 & $\begin{array}{l}\text { Website memberikan rasa percaya dalam melakukan } \\
\text { publikasi hasil penelitian }\end{array}$ & 3.800 & 4.350 & -0.550 \\
\hline s3 & $\begin{array}{l}\text { Website memberikan rasa aman pada infromasi pribadi } \\
\text { yang diberikan }\end{array}$ & 3.650 & 4.450 & -0.800 \\
\hline s4 & $\begin{array}{l}\text { Website membuat saya menjadi bagian dari suatu } \\
\text { komunitas yang berperan dalam e-journal Integrated } \\
\text { Lab Journal }\end{array}$ & 3.720 & 4.240 & -0.520 \\
\hline s5 & $\begin{array}{l}\text { Website memberikan kemudahan dalam berkomunikasi } \\
\text { dengan admin web e-journal Integrated Lab Journal }\end{array}$ & 3.580 & 4.200 & -0.620 \\
\hline s6 & $\begin{array}{l}\text { Website memberikan keyakinan bahwa paper yang } \\
\text { disubmit akan melalui proses editor sebelum } \\
\text { dipublikasi }\end{array}$ & 3.820 & 4.410 & -0.590 \\
\hline \multicolumn{2}{|c|}{ Rata-rata } & 3.710 & 4.306 & -0.596 \\
\hline
\end{tabular}

Hasil analisis pada Tabel 5 menunjukan bahwa nilai rata-rata harapan lebih besar dibandingkan dengan rata-rata kinerja. Nilai kesenjangan pada setiap indikator bernilai negatif, hal ini menunjukan bahwa website Integrated Lab Journal masih belum sesuai dengan harapan para responden.

Nilai kesenjangan tertinggi pada dimensi usability adalah indikator dengan kode u5, berdasarkan nilai -0.830 . Hal ini menunjukan bahwa responden memiliki harapan yang tinggi pada tampilan website yang menarik namun kinerja website masih belum mencapai harapan responden. Nilai kesenjangan tertinggi pada dimensi service quality adalah indikator dengan kode s3, berdasarkan nilai -0.800. Nilai kesenjangan pada kode s3 menunjukan bahwa website belum memberikan rasa aman pada informasi pribadi pengguna yang digunakan dalam website tersebut. Nilai kesenjangan tertinggi pada dimensi information quality adalah indikator dengan kode i1, berdasarkan nilai -0.690. Nilai kesenjangan pada kode il menunjukan bahwa harapan pengguna terhadap keakuratan infromasi masih belum terlaksana dalam kinerja. 


\section{4 Pengujian Importance Performance Analysis (IPA)}

Pengujian IPA menggambarkan indikator-indikator yang menjadi prioritas utama ketika akan dilakukan perbaikan hingga indikator-indikator yang sesuai dengan harapan penggunanya. Matriks IPA dibagi menjadi empat kuadran dalam suatu diagram.

Indikator-indikator dalam kuadran I sudah sesuai dengan harapan pengguna. Selanjutnya kuadran II menunjukan bahwa indikator-indikatornya memerlukan perbaikan dari pengembang website. Indikator-indikator yang masuk dalam kuadran III tidak terlalu membutuhkan perhatian. Terakhir adalah kuadran IV yang menunjukan bahwa indikator-indikator yang masuk dalam kuadran ini tidak terlalu penting namun memiliki performa yang baik sehingga dapat dialokasikan pada indikator lain yang membutuhkan prioritas. Diagram IPA Integrated Lab Journal dapat dilihat pada Gambar 3.

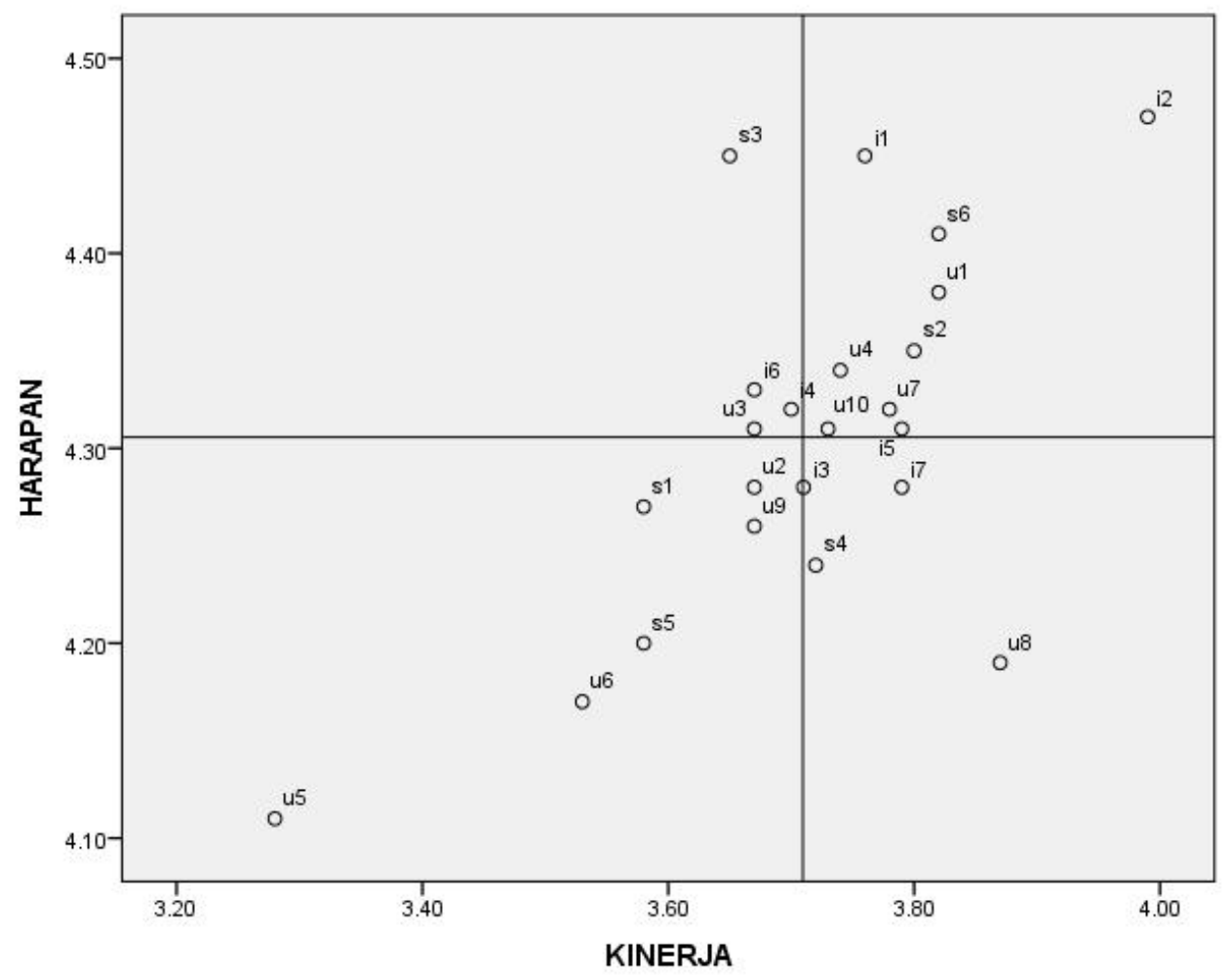

Gambar 3. Diagram IPA Integrated Lab Journal

Berdasarkan Diagram IPA pada Gambar 3, hasil pemetaan indikator dengan skala prioritas Importance Performace Analysis dijelaskan pada Tabel 6.

Tabel 6. Hasil Kuadran IPA Integrated Lab Journal

\begin{tabular}{|ll|ll|}
\hline \multicolumn{3}{|c|}{ Kuadran II } & \multicolumn{1}{|c|}{ Kuadran I } \\
\hline $\mathrm{u} 3$ & $\begin{array}{l}\text { Website dapat dijelajahi (dinavigasi) } \\
\text { dengan mudah }\end{array}$ & $\mathrm{u} 1$ & $\begin{array}{l}\text { Website mudah dipelajari cara } \\
\text { mengoperasikannya }\end{array}$ \\
i4 $\begin{array}{l}\text { Website menyediakan informasi yang } \\
\text { relevan sesuai dengan kebutuhan } \\
\text { pengguna }\end{array}$ & $\mathrm{u} 4$ & Website mudah digunakan \\
i6 $\begin{array}{l}\text { Website menyediakan informasi dengan } \\
\text { rincian yang lengkap }\end{array}$ & $\mathrm{u} 7$ & $\begin{array}{l}\text { Website mampu menjalankan fungsi } \\
\text { yang baik sebagai e-journal }\end{array}$
\end{tabular}

Mulyanto, et., al [Analisis Kualitas Website Integrated Lab Journal Menggunakan Webqual dan Importance Performance Analysis] 


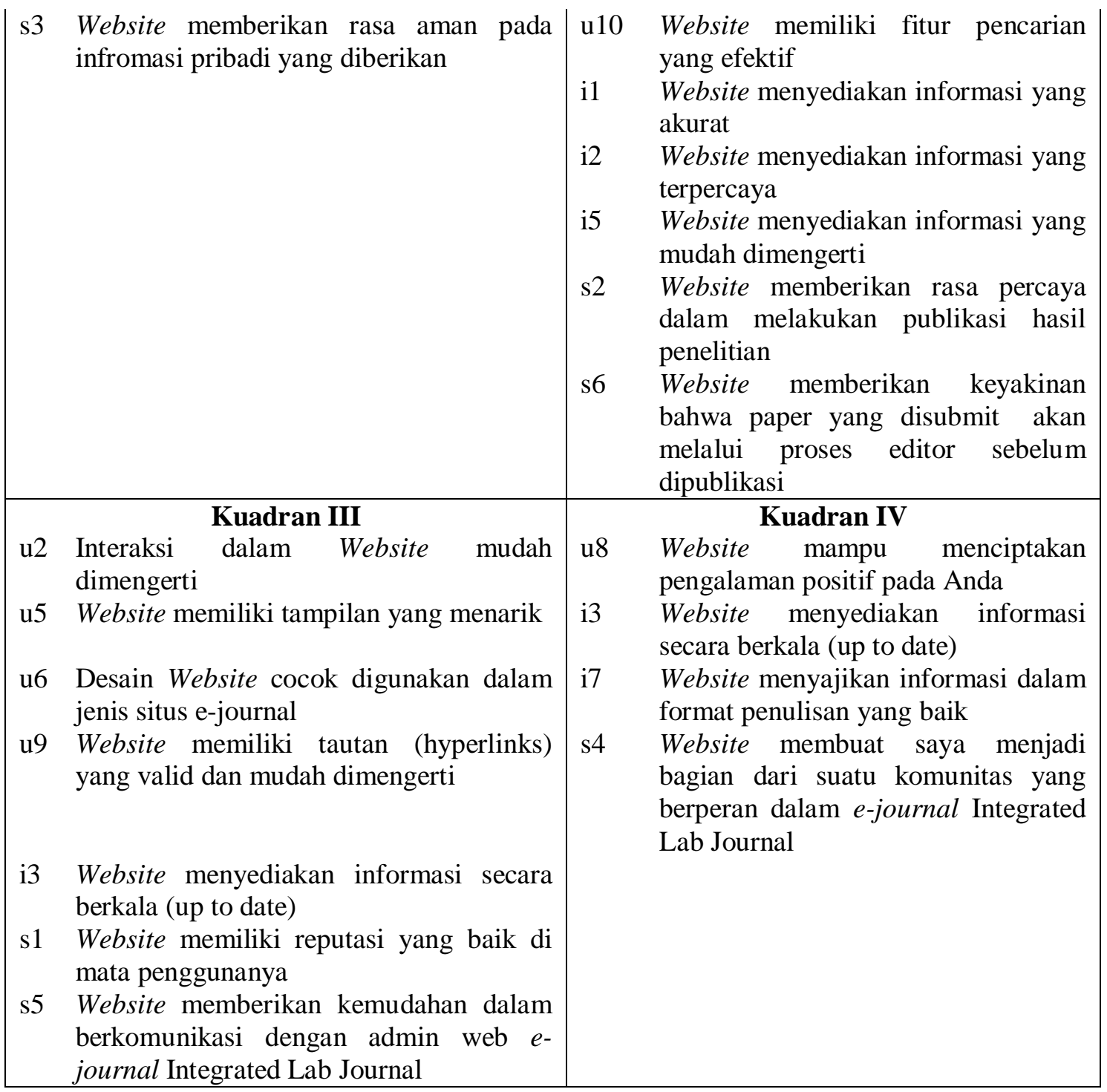

Tabel 6 menunjukan indikator-indikator pada setiap kuadran IPA. Kuadran yang memiliki indikator terbanyak adalah kuadran I, sebaliknya kuadran yang memiliki indikator paling sedikit adalah kuadran II dan IV.

Kuadran I memiliki 9 indikator yang harus dipertahankan kualitasnya, hal ini dikarenakan indikator-indikator tersebut telah memenuhi harapan pengguna. Kuadran II terdapat 4 indikator yang menjadi prioritas dalam perbaikan website karena tingginya harapan pengguna terhadap indikator tersebut, namun kinerja website belum sesuai dengan harapan pengguna. Indikator yang termasuk dalam kuadran II, yaitu indikator dengan kode u3, i4, i6, dan s3 mengenai kemudahan navigasi website, kesesuain informasi, kelengkapan informasi, dan keamanan data pribadi. Kuadran III terdapat 7 indikator yang tidak terlalu membutuhkan perhatian karena rendahnya harapan pengguna. Kuadran terakhir adalah kuadran IV yang memiliki 4 indikator. Indikator-indikator dalam kuadran IV termasuk sebagai indikator yang tidak penting tetapi memiliki kualitas yang baik, sehingga perhatian pengembangan pada indikator ini bisa dialihkan ke indikator lainnya. 


\section{KESIMPULAN}

Hasil pengujian kualitas website Integrated Lab Journal dengan metode Webqual dan pendekatan Importance Performance Analysis (IPA) mempunyai beberapa kesimpulan yaitu:

1. Nilai kesenjangan paling tinggi terdapat pada variabel usability (kegunaan) dengan kode indikator u5 yaitu mengenai tampilan website yang menarik. Indikator u5 memiliki nilai kesenjangan -0.830 . Nilai kesenjangan paling rendah terdapat pada variabel usability dengan kode indikator $\mathrm{u} 8$ yaitu mengenai pengalaman positif dalam penggunaan website. Indikator $\mathrm{u} 8$ memiliki nilai kesenjangan -0.320 .

2. Analisis Importance Performance Analysis menunjukan indikator yang membutuhkan perhatian untuk dilakukan perbaikan pada kuadran II. Indikator yang termasuk dalam kuadran II adalah u3, i4, i6, dan s3. Indikator-indikator tersebut berhubungan dengan kemudahan navigasi website, informasi yang relevan dan sesuai kebutuhan pengguna, informasi yang rinci dan lengkap, dan rasa aman ketika memberikan informasi pribadi. Indikator yang masuk dalam kuadran I merupakan indikator yang dinilai baik oleh pengguna. Indikator yang masuk dalam kuadran I adalah u1, u4, u7, u10, i1, i2, i5, s2, dan s6. Indikator-indikator tersebut berhubungan dengan kemudahan pengoperasian, kemudahan penggunaan, pelaksaan fungsi yang baik, pencarian yang efektif, keakuratan informasi, informasi dapat dipercaya, informasi mudah dimengerti, kepercayaan publikasi, dan keyakinan proses editorial.

\section{SARAN}

1. Berdasarkan hasil analisis kualitas dalam penelitian ini, diharapkan pengembang website Integrated Lab Journal memperbaiki indikator-indikator yang masuk dalam kuadran I yaitu $\mathrm{u} 1, \mathrm{u} 4, \mathrm{u} 7, \mathrm{u} 10, \mathrm{i} 1, \mathrm{i} 2$, i5, s2, dan s6. Indikator tersebut dapat digunakan sebagai prioritas dalam perbaikan yang dilakukan kedepannya

2. Penelitian selanjutnya, diharapkan dapat menggunakan metode pengukuran kualitas website lainnya seperti Netqual.

\section{UCAPAN TERIMA KASIH}

Penulis mengucapkan terima kasih kepada Ketua Lembaga Penelitian dan Pengabdian kepada Masyarakat (LPPM) Universitas Islam Negeri Sunan Kalijaga Yogyakarta yang telah memberi dukungan financial terhadap penelitian ini. Bantuan pembiayaan penelitian ini berdasar Berdasar Keputusan Rektor Universitas Islam Negeri Sunan Kalijaga Yogyakarta Nomor: 106.5 Tahun 2019 Tanggal 13 Juni 2019.

\section{DAFTAR PUSTAKA}

[1] Lukman dan Kustantyana, S. 2012, Manajemen Penerbitan Jurnal Ilmiah, CV Sagung Seto, Jakarta.

[2] Rahmaini, S. N. 2018, Analisis Kualitas Website Akademik Menggunakan Metode Webqual 4.0 dan Importance Performance Analysis (IPA), UIN Syarif Hidayatullah, Jakarta. 
[3] Gustina. 2018, Analisis Kualitas Website STIA Satya Negara Palembang Menggunakan Webqual dan Importance Performance Analysis, Konferensi Nasional Sistem Informasi 2018 STMIK Atma Luhur Pangkalpinang: http://jurnal.atmaluhur.ac.id/index.php/knsi2018/article/view/497

[4] Wibowo, dkk. 2019, Pengujian Usabilitas Portal Dutatani Menggunakan Metode Webqual dan Importance Performance Analysis (IPA), SNST, (12), pp. 1-12.

[5] Nisfiannoor, M. 2009, Pendekatan Statistika Moderen Untuk Ilmu Sosial, Salemba Humanika, Jakarta.

[6] Sunyoto, D. 2007, Analisis Regresi dan Korelasi Bivariat Ringkasan dan Kasus, Amara Books, Yogyakarta.

[7] Supriyadi, E. 2014, SPSS + Amos, IN MEDIA, Jakarta.

[8] Riduwan dan Akdon, 2013, Rumus dan Data Dalam Aplikasi Statistika, Alfabeta, Bandung.

[9] Barnes, S. dan Vidgen, R., 2002, An Integrative Approach to The Assessment of E-Commerce Quality, Journal of Electronic Commerce Research, pp. 114-127: https://www.researchgate.net/publication/220437591_An_Integrative_Approach_to_the_ Assessment_of_E-Commerce_Quality, Juni.

[10] Barnes, S, dan Vidgen, R., 2000, WebQual: An Exploration of Web-site Quality, ECIS, $\quad$ pp. 15-22: https://www.researchgate.net/publication/221408366_WebQual_An_Exploration_of_We b-Site_Quality, Juni.

[11] Latu, T, M. dan Everett, A. M., 2000, Review of Satisfaction Research and Measurement Approaches, Departmen of Conservation, Wellington. https://www.doc.govt.nz/Documents/science-and-technical/IR183.pdf

[12] Prastianto, B., 2007, Analisis Kualitas Situs Web Menggunakan Webqual Studi pad Forum Jual Beli Kaskus, Universitas Gadjah Mada, Yogyakarta.

[13] Anggraini, L. D., Deoranto, P., dan Ikasari, D. M., 2015, Analisis Persepsi Konsumen Menggunakan Metode Importance Performance Analysis dan Costumer Satisfaction Index, Jurnal Industri, Vol 4, No 2, pp. 74-81: https://industria.ub.ac.id/index.php/industri/article/view/179 